\title{
ВОЕННАЯ ДИПЛОМАТИЯ ПО-СУВОРОВСКИ
}

\section{MILITARY DIPLOMACY IN SUVOROVSKY D. Zausailov}

Summary: The paper describes the role of Generalissimo Alexander Suvorov in the reunification of Crimea with Russia in the latter half of the XVIII century when seen through the prism of recondite facts. It also seeks to draw analogy with the events that have taken place in the Crimea in 2014. Furthermore, the study represents an attempt to re-examine Suvorov's experience (the object of research), focusing on the key points of tactics and strategy, military psychology, craft of intelligence and diplomacy. The holistic method (systematic research approach) was shown to be an effective way of analyzing, compiling and new interpretation of already known facts.

Keywords: Alexander Suvorov, Crimea, Turkey, Aqyar Bay, Haji Meghmet, Shagin Giray, Pamir Giray, resettlement, 'Nativ' (Liaison Bureau), Alexandre de Langeron, Konstantinov, Makarov, Gambon, Prozorovsky, Abdul Hamid.
Меняются лишь времена, методы остаются те же Б.А. Березовский

Война - это путь обмана. Поэтому, даже если ты способен, показывай противнику свою неспособность. Когда должен ввести в бой свои силы, притворись бездеятельным. Когда цель близко, показывай, будто она далеко; когда же она действительно далеко, создавай впечатление, что она близко.

Сунь - Цзы. «Искусство войны»

«K рым наш» - эта фраза впервые зазвучала в XVIII веке благодаря А.В. Суворову. И хотя в иную эпоху всё Чёрное море именовалось Русским, современная история Крыма как части России берёт начало в годы правления Екатерины Великой. Подобно ситуации 2014 года, присоединение Крымского полуострова в далёком XVIII веке также проходило в несколько этапов.

В дважды позапрошлом столетии Крым являлся ничем иным, как «плацдармом» Османской империи для организации набегов на русские, украинские, польские и молдавские земли. Исходный момент перелома ситуации - Кючук-Кейнарджийский мирный договор. По нему в 1774 году Крым обрёл независимость от Турции. Фактическое же его присоединение к Российской империи - второй этап «партии» за полуостров. Завершающая стадия этой политической «двухходовки», то есть установление реального военно-политического влияния в Крыму - всецело заслуга будущего генералиссимуса А.В. Суворова.
Заусайлов Дмитрий Дмитриевич,

редактор-переводчик, Международное информачионное агентство «Россия сегодня» dzausailov@yandex.ru

Аннотация: В данной статье рассматривается роль генералиссимуса А. В. Суворова в присоединении Крыма к России через призму малоизвестных фактов. Приведено сравнение событий второй половины XVIII века с происходившим в Крыму в 2014 году. Объектом исследования является попытка по-новому рассмотреть опыт полководца А.В. Суворова с упором на ключевые моменты тактики и стратегии, военной психологии, искусства разведки и дипломатии. Основное внимание уделяется новой интерпретации и сведению воедино ранее известных данных посредством использования системного метода исследования.

Ключевые слова: Суворов, Крым, Турция, Ахтиарская бухта, Гаджи Мегмет,Шагин Гирей, Памир Гирей, переселение, «Натив», Ланжерон, Константинов, Макаров, Гамбон, Прозоровский, Абдул Хамид.

В жизни полководца до сих пор много «белых пятен», но крымский период интересен особо, так как вся деятельность Александра Васильевича в тот период обнаруживает в нём не столько военное начало, сколько характеризуют его как хитроумного дипломата, блистательного разведчика и отличного хозяйственника.

Такое амплуа А.В. Суворов не выбирал специально. Его ему диктовали сложившиеся условия, в частности возникновение несвойственных для армии того времени задач. Необъявленная, скрытая, партизанская, экономическая, гибридная война - так можно охарактеризовать современными понятиями то, что происходило на полуострове в период командования там Александра Васильевича. Акции военного устрашения, демонстрация силы, поддержка политических ставленников центральной власти, развитие торговли, переселение народов, организация пограничной службы, разведки, примирение враждующих сторон - весь этот пласт непростых задач лёг на плечи полководца в марте 1778 года, когда генерал-поручик А.В. Суворов принял командование войсками в Крыму и на Кубани.

Для примера рассмотрим сначала эпизод с Ахтиарской бухтой, мало кому тогда известной. Лишь сегодня мы понимаем, о чём идёт речь - на берегах этой бухты стоит город Севастополь. Сама она уже давно переименована в «Севастопольскую» и стала настолько удобной для навигации и размещения судов, что уже в наши дни с ней могут посоперничать лишь Сиднейская и Гонконгская бухты. Но тогда, в конце XVIII века первым из крупных военачальников своё внимание на это стратегиче- 
ски важное место обратил не кто иной, как Александр Васильевич: «Подобной гавани не только у здешнего полуострова, но и на всем Черном море другой не найдется, где бы флот лучше сохранен и служащие на оном удобнее и спокойнее помещены были...» - писал он в те годы [1].

Турецкие адмиралы в то время аналогично понимали ценность данного стратегического объекта. В итоге, презрев условия Кючук-Кейнарджийского мира, они разместили в бухте с десяток своих кораблей. Кроме того, стремясь к реваншу, Порта направила в Чёрное море ещё три эскадры.

Екатерина II поставила командованию российского флота и сухопутных сил чёткую задачу: противостоять высадке турецкого десанта на данном направлении. За её выполнение взялся А.В. Суворов, справедливо считая, что лучшим решением проблемы станет вытеснение турок из самой бухты. Но разрешить дело саблей в тот момент - наихудший вариант. Умело используя случай, молодой генерал поступил иначе.

В один из дней турецкими матросами был убит русский казак. Командиром Крымского корпуса было выдвинуто требование найти и выдать убийцу. На этот запрос командующий турецким флотом отреагировал непоследовательно: дипломатично уверил российскую сторону в лице А. В. Суворова в дружбе, однако само дело «спустил на тормозах».

Александр Васильевич ответил проведением оригинальной военно-дипломатической акции. По его приказу шесть пехотных батальонов под покровом ночи приступили к возведению батарей по обеим сторонам входа в бухту. Места их возведения выбирались лично А.В. Суворовым и были вовсе не случайны: именно там батареи позволяли моментально перекрыть артиллерийским огнём вход и выход кораблей из бухты.

Турецкий адмирал Гаджи Мегмет, обнаружив поутру эту неожиданную для себя картину обстановки, потребовал разъяснений. А.В. Суворов ответил подобным полученному им ранее письмом, в котором уже он высказывал большое уважение к турецкому «коллеге», и сводил всё объяснение к выражению мирных и дружественных намерений [2].

На следующий день батареи лишь увеличились, что создало реальную угрозу для блокирования турецких кораблей в бухте. Гаджи Мегмету не оставалось ничего, кроме как отдать приказ о выводе кораблей из залива. При этом турки ещё пару недель находились в прибрежных водах, выжидая развития ситуации. И вот уже 170 судов противника блокировали крымские берега. Однако и на этот случай у А.В. Суворова был заготовлен простой и гениальный план - на запрос турецкой стороны сойти на берег «для прогулки и набора пресной воды» Александр Васильевич дал жёсткий отказ, мотивируя запрет тем, что турецкие корабли прибыли из портов, где фиксировались вспышки чумы. Аналогично, чума и засуха на самом полуострове «не позволили» русским войскам поделиться с «дорогими турецкими гостями» и каплей пресной воды («...во охранение от той привредной заразы учрежденный карантин не позволяет отнюдь ни под каким предлогом спустить на берег ни одного человека из ваших кораблей!») [3]. Туркам пришлось удалиться в Босфор ни с чем. Так суворовские войска впервые «вежливо» отстояли Крым без единого выстрела.

Одновременно с «Ахтиарской операцией» по поручению Г.А. Потёмкина А.В. Суворов приступает к осуществлению масштабной акции по переселению христиан греков, армян, грузин - из Крыма в земли Новороссии. Вся организационная работа, по сути, легла тогда на плечи одного человека. Для сравнения, в XX веке для выполнения схожих задач в течение более длительного времени в Израиле понадобилась целая профильная

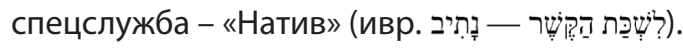

Официальный повод к началу данного предприятия - спасение христианского населения от мусульманского гнёта. Но чем же это было на самом деле? В зависимости от цели, ответ будет разным: для школьного учебника истории подойдёт слово «переселение», «добровольный исход», а журналистская статья с претензией на сенсационность или изобличающая власть будет пестрить терминами вроде «насильственная депортация», «выселение». Жёсткие сроки и порядок переселения, применение силы, случаи вынужденного перехода христиан в мусульманство в целях остаться на Родине; одновременно выделение земли переселенцам, освобождение их от налогов и рекрутской повинности - всё это имело место. Был пряник, был кнут. Но являлось ли «убережение от мстивого ятагана» лейтмотивом данных событий? Лишь отчасти. Поэтому акцию А.В. Суворова скорее следует назвать «ассиметричными действиями» в контексте военно-политической операции.

Эта операция как часть экономической войны на полуострове имела целью лишить крымского хана важнейшей категории налогоплательщиков, дабы упрочить позиции центральной власти на полуострове. Речь идёт о последнем крымском хане Шагин Гирее. Кем был этот хан? Патриотом своей малой Родины - Крыма, политическим ставленником Санкт-Петербурга или же «агентом влияния» Турции? Вероятно, он сочетал в себе эти роли.

На самом начальном этапе вхождения полуострова в орбиту влияния России первостепенной задачей российского военного командования стала дача отпора туркам, затем возникла необходимость «примирения» правящих на полуострове политических кругов и вы- 
движения «своего человека» в качестве хана. Тогда выбор пал на кандидатуру Шагин Гирея (рис. 1), молодого, умного и амбициозного человека.

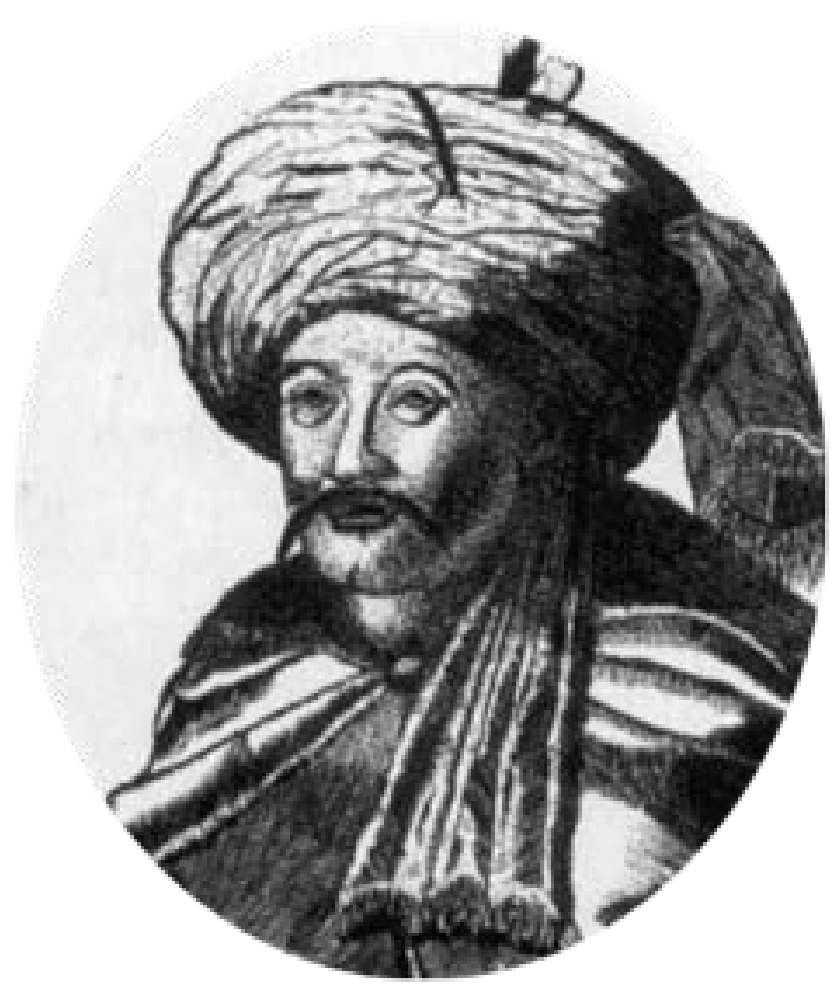

Рисунок 1. Шагин Гирей. Последний крымский хан.

Его противник и конкурент - Девлет Гирей - был «устранён» при помощи «суворовских штыков». Такая деликатная работа была проделана А.В. Суворовым в высшей степени профессионально, без капли пролитой крови и в обход формального действия тогдашнего «международного права». Войско Девлет Гирея Александр Васильевич рассеял одними лишь манёврами своих вооружённых сил, сознательно не вступая в боестолкновения.

В инструкциях «суворовцам» - пехотинцам, драгунам и казакам - русский генерал требовал избегать конфликтов, воздерживаться от применения силы и оружия, «с покорившимися соблюдать полное человеколюбие» [4] (читай «быть вежливыми»).

Стоит отметить, что война тогда велась и на «невидимом фронте». В этих условиях А.В. Суворов выступал также в роли начальника контрразведки, направляя «своих людей» (например, полковников Макарова и Гамбома) для захвата и/или скрытой физической ликвидации тайных агентов Турции, действовавших в Крыму под видом купцов [5].

Тем не менее, как показало время, ставка на Шагин Гирея не оправдалась. Получив власть, он демонстрировал прямо-таки диктаторские наклонности: казнил недо- вольных и взвинчивал налоги, стремясь устроить свой быт, жизнь полуострова и армии по западному образцу. Пристрастиями к роскоши, каретам, французской кухне и неуважением к традициям он нажил себе врагов даже среди значительной части мусульман. Этим воспользовалась Турция, подослав своего ставленника Селим-Гирея и осуществив его руками политический переворот. Таким образом мятеж перекинулся на всю территорию полуострова. Шагин Гирей бежал в расположение русских войск, которые, в свою очередь, двинулись обратно к Бахчисараю. Под командованием растерянного командующего корпусом российских войск в Крыму А.А. Прозоровского (предшественник А.В. Суворова на этом посту) они уничтожили две тысячи заговорщиков и силой вернули власть Шагин Гирею.

Александр Васильевич же с самого начала решил действовать иным образом. С момента вступления в должность командующего Крымским корпусом, А.В. Суворов стал «связующим звеном» между Санкт-Петербургом, русским дипломатическим корпусом, представителями церквей и местной знатью, то есть аккумулировал большой массив оперативной информации [6]. Он специально завязал отношения с греческим митрополитом в целях официального «признания» возможности переселения и ведения посредством него соответствующей пропаганды среди христиан полуострова. После возврата в Крым в феврале 1779 г. Александр Васильевич «виделся и беседовал со многими ногайскими султанами, вникал в их отношения и в положение дел» [7]. При этом, оказавшись в Бахчисарае, он установил дружеские отношения и с новым ханом: наносил неформальные визиты, пил с ним кофе, играл в шахматы, одновременно выслушивая и ненавязчиво поправляя инициативы и решения своего собеседника. «Правой рукой» и помощником А.В. Суворова в то время являлся русский резидент (устар. «дипломатический представитель, посол») в Крыму по фамилии Константинов, ставший впоследствии близким другом полководца и крестным отцом его дочери. (Любопытным фактом является то, что 18 марта 2014 года Председатель Государственного Совета Республики Крым В.А. Константинов подписал международный Договор о принятии Республики Крым в Российскую Федерацию).

Другими словами, Александр Васильевич в своей деятельности не разделял военную сферу и политическую, демонстративно выставляя напоказ успехи лишь в первой и тщательно скрывая свои действия во второй. На Западе такой стиль поведения часто приписывают легендарному директору ЦРУ США Аллену Даллесу. О нём говорили следующее: «Даллес был первым офичером разведки, который имел смелость распространить свою деятельность на политические аспекты войны» [8]. Теперь же очевидно, что пионером подобных методов легендарный шеф ЦРУ всё же не являлся, как мини- 
мум, в сравнении с А.В. Суворовым. Не зря современник генералиссимуса, будущий генерал-губернатор Новороссии и Бессарабии (с 1815 по 1822 год) А.Ф. Ланжерон, имевший честь общаться с А.В. Суворовым лично, вспоминал об Александре Васильевиче: «Это великий полководец и великий политик...» [9].

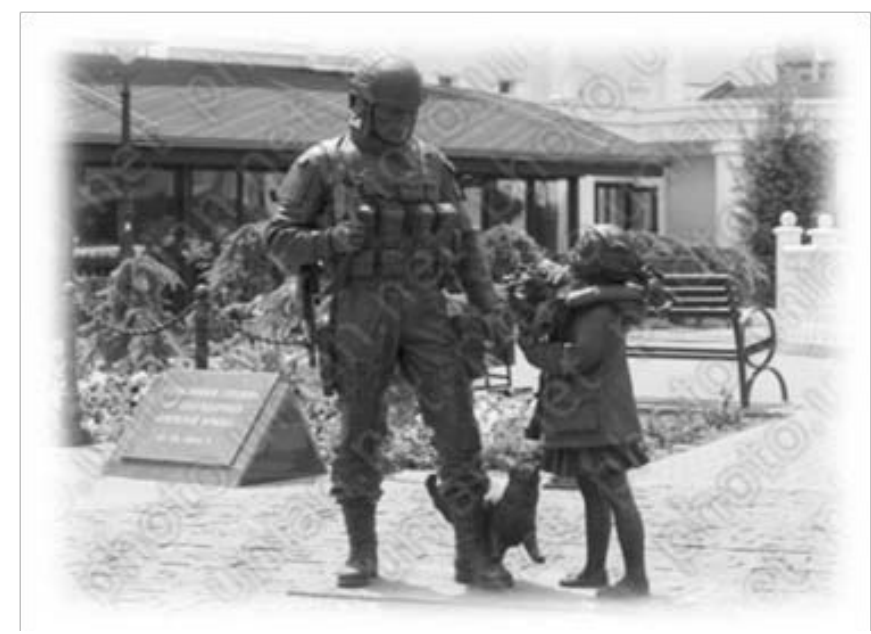

Рисунок 2. Памятник «Вежливым людям» в Симферополе.

На памятнике нашлось место даже бронзовому коту, а вот А. В. Суворов попросту «не вписался в композицию». Сегодня всё меньше людей помнят о том, что именно ему страна обязана русским Крымом как таковым.

Между тем, Шагин Гирей сразу же после возврата власти в Крыму продолжил проводить карательную политику. Даже его родные братья Бадыхар и Арслан были буквально спасены от смертной казни лишь по решению Санкт-Петербурга. «Добровольно-принудительное» отречение Шагин Гирея от ханского престола состоялось 14 апреля 1783 года, а 19 апреля того же года, согласно манифесту Екатерины II, Крым был включён в состав Российской империи.

В целях стабилизации обстановки на полуострове хану было вежливо предписано переехать в центральные области империи. За столь неоднозначное, но всё же «сотрудничество», его ждала вполне достойная плата - Андреевский орден, переделанный специально для мусульманина и солидная ежегодная пенсия.

После нескольких предупредительных писем хан всё же выехал из Крыма, но проживать в другом месте отказался. Свой отказ он выразил весьма своеобразно - посредством «эмиграции» в Османскую империю, где в 1787 года на о. Родос был казнён по приказу султана Абдул-Хамида, а там, как говорится, и «концы в воду».

Интересно, что посланник России в Турции А.И. Булгаков незадолго до смерти Шагин Гирея делился своими наблюдениями: «Не знаю истинной причины перехода сюда Шагина, но он сам просится о возвращении и раскаивается тысячу раз о сей глупости» [10]. Примечательной ремаркой послужит тот факт, что Шагин Гирей был удавлен шёлковым шнуром [11].

Узнаем ли когда-нибудь всю правду о жизни хана и его связях с Турцией? Шансы такого расклада примерно равны шансам ознакомления с делом другого человека с большими деньгами, который сыграл значительную роль в истории уже современной России. Он также подался за границу, пожалел об отъезде и, кажется, мечтал вернуться. Однажды в своём имении в Лондоне он якобы повесился на шёлковом шарфе, «переживая за долги». Закрытые похороны. Закрытый гроб. Закрытый город и краткие репортажи российских СМИ, которыми он прежде руководил. Именно так работает многовековая практика защиты свидетелей в Великобритании. Важно ли это сегодня? Причём здесь суворовская эпоха? Вероятно, ни при чём, как и то совпадение, что в Лондоне в настоящее время проживает Джеззар Раджи Памир Гирей - наследник дома Гиреев, официально заявивший свои права на Крымский престол... Меняются лишь времена, методы остаются те же...

1. Ганичев В. Ушаков. М., 1990. С. 150.

ЛИТЕРАТУРА

2. Суворов А.В. Документы (под общей редакцией полковника Г. П. Мещерякова). 18 июня 1778 г. - Письмо А.В. Суворова командующему турецким флотом Гаджи-Мегмет-Аге с уверениями в дружбе и желании сохранить мир. Т.ІІ. М.: Воениздат, 1951. С. 70.

3. Суворов А.В. Документы (под общей редакцией полковника Г. П. Мещерякова). 11 сентября 1778 г. - Письмо А.В. Суворова Гаджи-Али-Паше и ГассанПаше о запрещении туркам сходить с кораблей на берег. Т.ІІ. М.: Воениздат, 1951. С. 113-114.

4. Петрушевский А.Ф. Генералиссимус князь Суворов. Изд. 2-е. - СПб.: Тип. М.М. Стасюлевича, 1900. - 788 с.

5. Суворов А.В. Документы (под общей редакцией полковника Г. П. Мещерякова). 27 июня 1778 г. - Рапорт А.В. Суворова П.А. Румянцеву о посылке Турцией тайных агентов в Крым и на Кубань и мерах, принятых для их поимки. Т.ІІ. М.: Воениздат, 1951. С. 83-84.

6. Соловьев С.М. История России в царствование Императрицы Екатерины II. Том V. Москва, 1879.

7. Петрушевский А.Ф. Генералиссимус Князь Суворов. - М.: Культурно-просветительский Русский издательский центр имени святого Василия Великого, 2016. - 1096.: ил., карты. с. 121.

8. Воропаев С. Энциклопедия Третьего Рейха. Локид - Пресс, 2005. «Д» Даллес Аллен Уэлш. 
9. Шильдер Н.К. Русская армия в год смерти Екатерины II. I-IV [Текст]: Состав и устройство русской армии. - [Б. м.] : [6. и.], [1885]. Отр. из «Рус. (тарина», 1885, т. 83, март-апр., с. 147-166, 145-177, 185-202.

10. Лашков Ф.Ф. Л32 Шагин-Гирей, последний крымский хан. Ист. очерк. «Ордера секунд-майору Розенбергу, бригадиру Фону и Арабатскому коменданту Каховскому», 7 февраля 1786 г. Донесение Караценова. (Из дела «0 ханской свите»). Симферополь: Редотдел Крымского облполиграфиздата. 1991.

11. Лашков Ф.Ф. ЛЗ2 Шагин-Гирей, последний крымский хан. Ист. очерк. «Ордера секунд-майору Розенбергу, бригадиру Фону и Арабатскому коменданту Каховскому», 7 февраля 1786 г. Донесение Караценова. (Из дела «0 ханской свите»). Симферополь: Редотдел Крымского облполиграфиздата. 1991. Там же на странице 48.

( З Заусайлов Дмитрий Дмитриевич (dzausailov@yandex.ru).

Журнал «Современная наука: актуальные проблемы теории и практики»

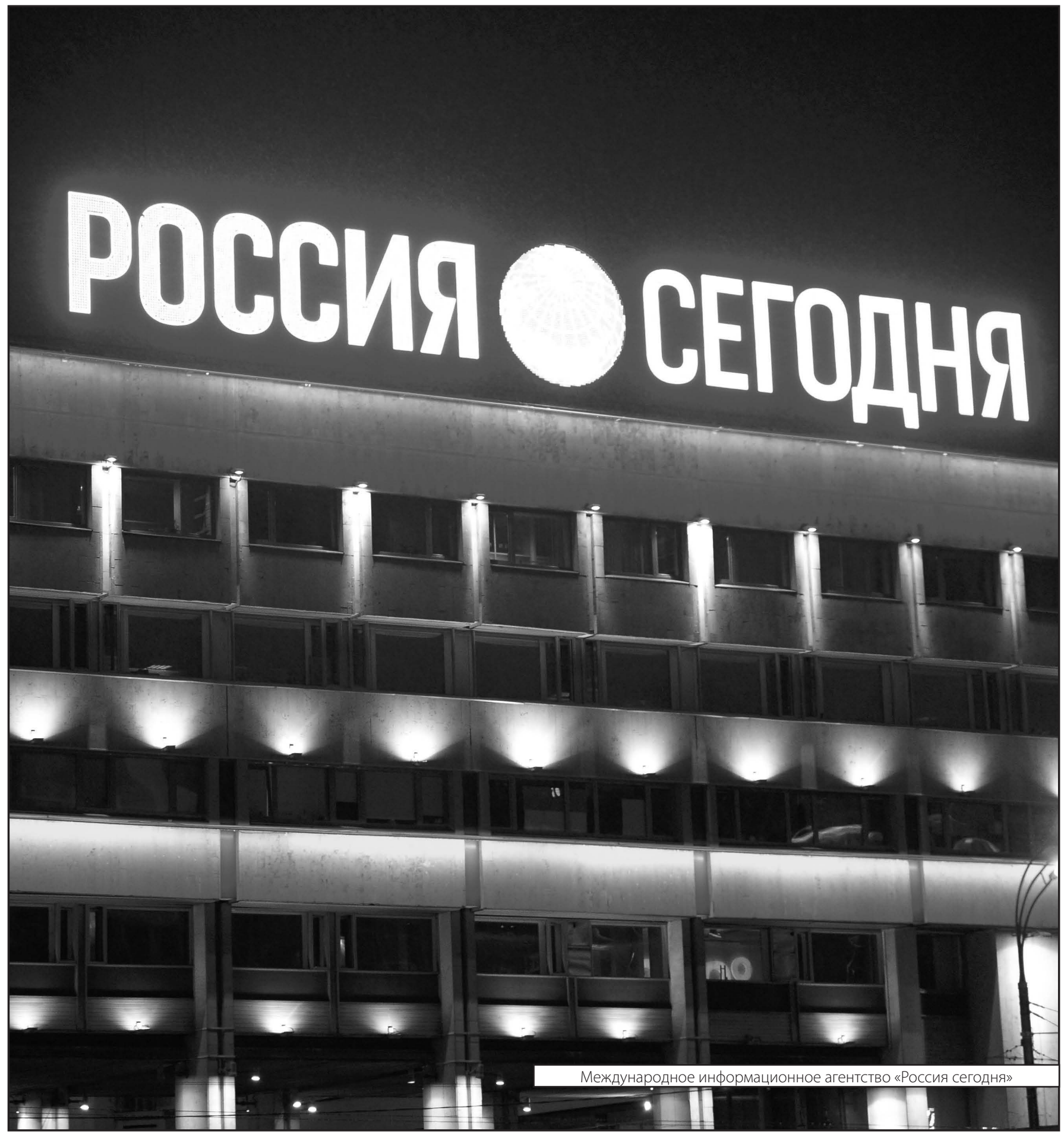

